Case Study

\title{
Field performance of bacteria-based repair system: Pilot study in a parking garage ${ }^{2}$
}

\author{
V. Wiktor*, H.M. Jonkers \\ Delft University of Technology, Delft, The Netherlands
}

\section{A R T I C L E I N F O}

\section{Article history:}

Available online 9 January 2015

\section{Keywords:}

Concrete

Repair

Bacteria-based system

Crack

\begin{abstract}
A B S T R A C T
This paper presents the field performance in a parking garage of the recently developed bacteria-based repair system for concrete. This liquid-based repair system aims at the sealing of cracks and decrease of the porosity due to the production of a calcium-based biomineral. The system combines advantages of both a traditional repair system for concrete (fast reacting and short term efficiency), and bio-based methods (more sustainable, slow process, and long-term efficiency).

The bacteria-based repair system has been sprayed onto the surface of cracks and on concrete pavement. The crack-sealing efficiency and improvement of frost salt scaling were assessed by water permeability and freeze/thaw resistance tests respectively. The results were very promising as only cracks that had not been treated with the bacteriabased repair system were still heavily leaking. In addition, the freeze/thaw resistance of concrete that was treated with the bio-based repair system was higher than the untreated concrete.
\end{abstract}

(c) 2015 The Authors. Published by Elsevier Ltd. This is an open access article under the CC BY-NC-ND license (http://creativecommons.org/licenses/by-nc-nd/4.0/).

\section{Introduction}

Concrete is the most used construction material worldwide. Indeed, even if exposed to a number of degradation processes such as carbonation or chloride ingress, concrete structures can reach a service life of more than 50 years (Emmons and Sordyl, 2006). However the presence of cracks, and the subsequent ingress of aggressive corroding substances, is a major limitation for the durability. This leads to the premature corrosion of the reinforcement and early failure of the structure. As a result, costly measures for maintenance and repair are undertaken. Nowadays a wide range of repair products, such as for instance epoxy-based fillers or silane-based water repellent, is available for concrete. However, the short term efficiency and negative impact on the environment are an issue for the repair industry.

Biodeposition, a method by which calcium carbonate $\left(\mathrm{CaCO}_{3}\right)$ precipitation is induced by bacteria, has been proposed as an interesting alternative approach to protect building materials. Various pathways are involved in Microbial Induced Precipitation (MIP) process. Among them, enzymatic hydrolysis of urea in a calcium rich environment is the most commonly

\footnotetext{
This paper was presented at Concrete Solutions, the 5th International Conference on Concrete Repair. It can be found in the conference proceedings: Michael Grantham, P.A. Muhammed Basheer, Bryan Magee, Marios Soutsos, Concrete Solutions 2014, CRC Press, 2014.

* Corresponding author.

E-mail address: v.a.c.wiktor@tudelft.nl (V. Wiktor).
} 
used system (Dhami et al., 2012). Successfully applied as a surface treatment in practice to limestone monuments, it has been considered only on a laboratory scale for cementitious material and crack repair.

Also, besides cost issues, MIP using ureolytic bacteria might generate other problems, such as environmental nitrogen loading due to the production of ammonia during the hydrolysis of urea or negative effect to the material itself due chemical reactions with ammonium salt (Dhami et al., 2012). In addition, the time required for a substantial amount of bacterially induced calcium carbonate may hold back the acceptance of MIP as an efficient repair technique by the building industry.

Bacterially mediated calcite precipitation thanks to metabolic conversion of calcium lactate instead of urea hydrolysis has been successfully applied in self-healing concrete (Wiktor and Jonkers, 2010). The authors implemented this concept for the development of bio-based repair system for a real concrete structure. The novelty of such a system is to combine advantages of both a traditional repair system for concrete and bio-based methods (Wiktor and Jonkers, 2011, 2012a).

In this way, a silicate-based compound, which has a composition similar to concrete, is associated with MIP without involving a urea hydrolysis pathway. Instead, the metabolic conversion of organic salts through bacterial respiration is used for MIP.

The bio-based repair system as presented in this paper is a liquid-based system which transports the bio-based agent into concrete. This paper investigates and discusses the field performance of the bacteria-based system developed in the laboratory.

\section{Materials and methods}

\subsection{Bacteria-based repair system}

The repair system consists of concrete compatible bacteria (Wiktor and Jonkers, 2012b) and feed which produce calcitebased minerals decreasing concrete porosity. This system is composed of two solutions:

(i) Solution A - sodium-silicate (alkaline buffer), sodium-gluconate (carbon source for bacteria growth), alkaliphilic bacteria.

(ii) Solution $\mathrm{B}$ - calcium-nitrate (nitrate source for denitrification when $\mathrm{O}_{2}$ is depleted and calcium for $\mathrm{CaCO}_{3}$ precipitation), alkaliphilic bacteria.

The denitrification is the biological reduction of nitrogenous oxides to gaseous products during anaerobic (no oxygen) bacterial growth. This means that under the metabolic conversion of calcium nitrate, $\mathrm{N}_{2}$ and $\mathrm{CaCO}_{3}$ are produced.

The silicate-based compound, sodium silicate, ensures an alkaline $\mathrm{pH}$ in the system and the formation of a gel inside the crack. Although not very strong, this gel allows a rapid sealing of the crack (within a few hours) and an optimum environment for bacteria to precipitate calcium carbonate. By the time the gel becomes too weak, a substantial amount of $\mathrm{CaCO}_{3}$ has been precipitated to seal the crack.

\subsection{Test location: parking garage}

The test location was a 2 storey underground parking garage with a capacity of 300 parking places.

The concrete deck was suffering from cracking which resulted in significant leakage of the structure (Fig. 1a). Also, the concrete pavement on each side of the access ramp was damaged due to freeze/thaw (Fig. 1b).

\subsection{Application of the bacteria-based repair system}

Part of the concrete pavement (area of $2 \mathrm{~m} \times 0.5 \mathrm{~m}$ ) and three cracks $(1-3 \mathrm{~mm}$ wide) of the concrete deck were impregnated with the bacteria-based repair system. Solution A and solution B were each poured in a sprayer, and manually applied at the surface of the concrete in layers until saturation of the concrete treated area.

\subsection{Evaluation of the efficiency of the repair system}

Two months after the application of the bacteria-based repair system, 6 cores were drilled (Fig. $2 \mathrm{a}$ and b) from two different locations on the concrete pavement: 3 from the treated area and 3 from an untreated part on the same side of the access ramp as control specimens. The resistance of the treated and untreated concrete to freeze/thaw conditions and deicing salt was then evaluated in laboratory.

The crack-sealing efficiency of the bacteria-based repair system was assessed by means of a water permeability test performed on site on 3 treated- and 3 untreated cracks (Fig. 2c).

\subsubsection{Resistance to freeze/thaw and deicing salt}

The 6 concrete cores were tested according the NPR-CEN/TS 1239-9 (Testing hardened concrete - Part 9: Freeze/thaw scaling) and NEN-EN 13877-2 (Concrete pavement - Part 2: Functional requirements for concrete pavements). The test was 


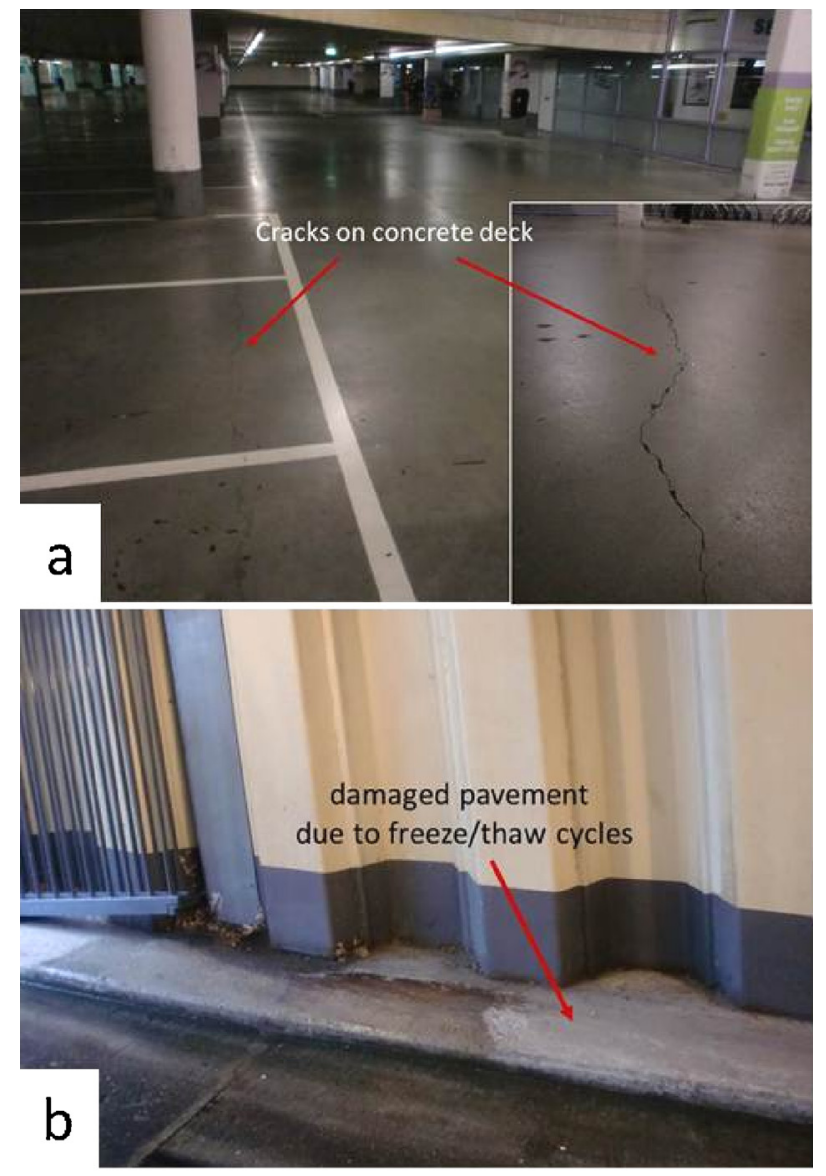

Fig. 1. Test location for the application of the bacteria-based repair system. (a) Cracks on the concrete deck, (b) pavement on the side of the access ramp.

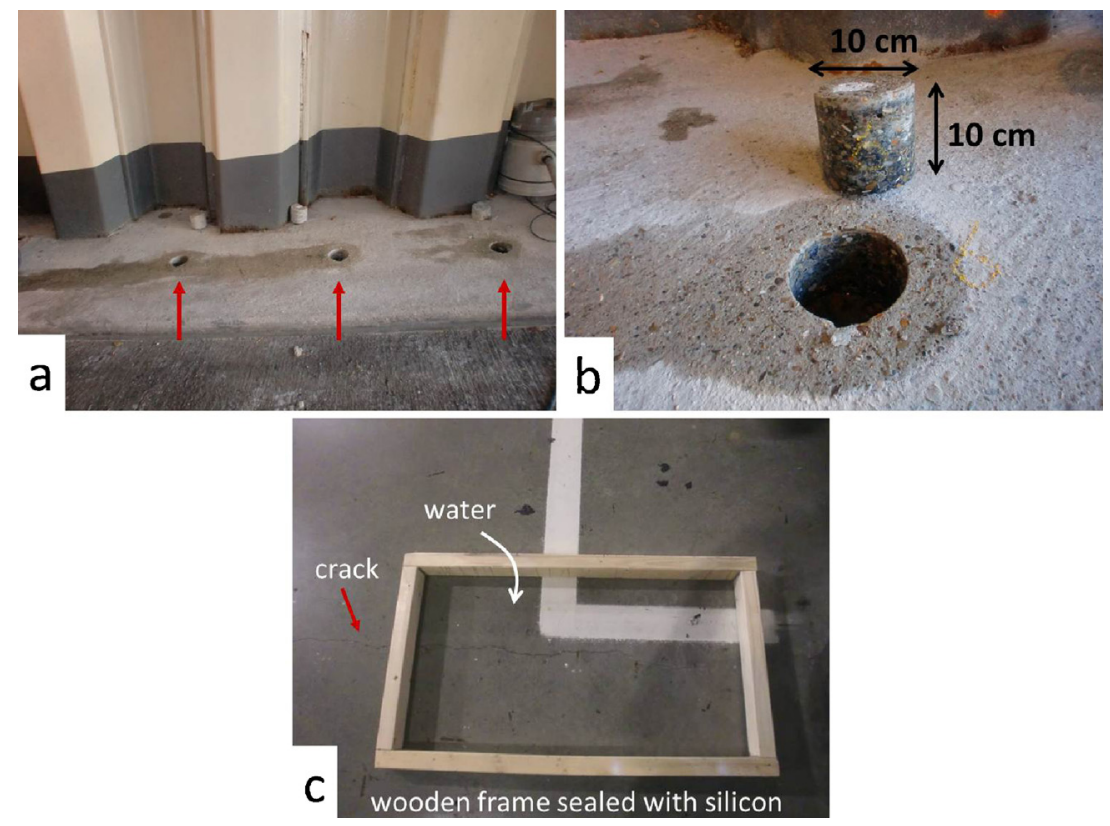

Fig. 2. Evaluation of the repair system's efficiency. (a) Cores drilled on the concrete pavement, (b) detail of a core, (c) water permeability testing. 
performed independently by Cugla B.V. (Breda, The Netherlands). If the specimens are damaged in such a way that the mass loss is $>1 \mathrm{~kg} / \mathrm{m}^{2}$, the test is stopped. Indeed, a mass loss $>1 \mathrm{~kg} / \mathrm{m}^{2}$ means that the concrete has a poor resistance to freeze/thaw and fits in the lowest category (FT0) according to NEN-EN 13877-2.

\subsubsection{Water permeability test}

The goal of this test was to have a rapid and practical evaluation of the crack sealing on site. For this purpose, rectangular wooden frames $(1 \mathrm{~m} \times 0.5 \mathrm{~m})$ were placed on top of the concrete deck in such a way that the crack went through the full length of the rectangle (Fig. 2c). The wooden frames were positioned on top of 3 cracks treated with the bacteria-based repair system and 3 non-treated cracks for control.

The wooden frames were sealed with silicon glue prior to pouring in $5 \mathrm{~L}$ of tap water. As the crack went through the whole thickness of the deck, the sealing efficiency was assessed by monitoring visually, from the other side of the deck, how much water was dripping through the crack (Fig. 3).

\section{Results and discussion}

\subsection{Resistance to freeze/thaw and deicing salt}

The results of the laboratory testing for scaling resistance with deicing salt are given in Figs. 4 and 5 .

The test was stopped after only 7 cycles as specimens treated with the bacteria-based repair system and the control ones, both exhibited a mass loss $>1 \mathrm{~kg} / \mathrm{m}^{2}$. The concrete tested had a very poor resistance to freeze/thaw with de-icing salt.



Fig. 3. Schematic representation of the water permeability test performed.



Fig. 4. Scaling after 7 freeze/thaw cycles. 




Fig. 5. Observation of the control core \#2 before (a) and after (c) 7 freeze/thaw cycles and treated core \#5 before (b) and after (d) 7 freeze/thaw cycles.

However, a closer look to Figs. 4 and 5 shows that the specimens treated with the bacteria-based repair system had a significantly lower mass loss (scaling) compared to the control, $1.9 \pm 0.3 \mathrm{~kg} / \mathrm{m}^{2}$ and $3.6 \pm 1.3 \mathrm{~kg} / \mathrm{m}^{2}$ on average respectively.

Though treated and untreated concrete specimens falls into the lowest category (FT0) for scaling resistance, the results however suggest that the treatment with the bacteria-based system tended to improve the resistance of the concrete to freeze/thaw.

Of course, other parameters should also be taken into account while interpreting these results such as the type of cement, mix composition or environmental factors. However, it should be noticed that very little is known about the history of this concrete. To our knowledge, the parking garage was built in 2005. The concrete has been exposed over the years to significant carbonation and freeze/thaw episodes.

Considering that the parking garage is located in the Netherlands and on a coastal area, most probably blast furnace slag cement was used.

Moreover, concretes with high slag content are known to have a lower carbonation resistance compared to Ordinary Portland Cement (OPC) which makes it more vulnerable to frost salt scaling (Copuroglu, 2006). Indeed, carbonation of slag cement results not only in calcite formation as for OPC, but leads also to aragonite and vaterite formation. The combined attack of frost and chloride results in the dissolution of aragonite and vaterite and thus in microstructure coarsening (Richardson, 2006).

Therefore, based on the available information and present results, the application of the bacteria-based repair system appears as a promising approach to improve the resistance of concrete to freeze/thaw with de-icing salt. It is likely that the decrease in porosity and densification of the pore system is due to biomineral precipitation. However, further investigation on the microstructure of the concrete should be performed in order to confirm this statement.

\subsection{Water permeability test}

The crack-sealing efficiency was visually assessed on site. The results were very encouraging as the 3 control cracks were heavily leaking (Fig. 6a-c) along the full tested length while 2 cracks treated with the bacteria-based repair system exhibited only a few localized dripping spots (Fig. $6 \mathrm{~d}$ and e). The third treated crack was not leaking at all. 



Fig. 6. Observation of water leaking through the cracks during water permeability test - (a-c) control non treated cracks, (d and e) cracks treated with the bacteria-based repair system.

\section{Conclusion}

This paper presents the field performance of the recently developed bacteria-based repair system for concrete. The system combines advantages of both a traditional repair system for concrete (fast reacting and short term efficiency), and bio-based methods (more sustainable, slow process, and long-term efficiency).

The bacteria-based repair system has been sprayed on the surface of cracks and on a concrete slab in an underground car park. The crack-sealing efficiency and improvement of frost salt scaling were assessed by water permeability and freeze/ thaw resistance tests respectively. The results were very promising as only cracks that had not been treated with the bacteria-based repair system were still heavily leaking. In addition, the freeze/thaw resistance of concrete that had been treated with the bio-based repair system was significantly higher than the untreated concrete.

These results are very encouraging for the application in practice of the bacteria-based repair system. The system is currently being optimized in order to raise its performances to complete sealing of the cracks and to develop better frost salt scaling resistance. A next step is also to assess the long term performance of the bacteria-based repair system.

\section{Acknowledgments}

The authors would like to thank Cugla B.V. (Breda, The Netherlands) for testing the resistance of the concrete cores to freeze/thaw.

Financial support from Agentschap NL (IOP Grant SHM012020) for this work is gratefully acknowledged.

\section{References}

Copuroglu O. The characterisation, improvement and modelling aspects of frost salt scaling of cement-based materials with a high slag content.. [PhD thesis] Delft, The Netherlands: Delft University of Technology; 2006. 
Dhami NK, Reddy SM, Mukherjee A. Biofilm and microbial applications in biomineralized concrete. In: Seto J, editor. Advanced topics in biomineralization. Rijeka: In Tech; 2012. p. 137-64.

Emmons PH, Sordyl DJ. The state of the concrete repair industry, and a vision for its future. Concr Repair Bull 2006;7-14.

Richardson DN. Strength and durability of a 70\% ground granulated blast furnace slag concrete mix.. Technical report RI99.035/RI99.035B University of MissouriRolla; 2006.

Wiktor V, Jonkers HM. Quantification of crack-healing in novel bacteria-based self-healing concrete. Cem Concr Compos 2010;33:763-70.

Wiktor V, Jonkers HM. Development of bacteria-based systems to increase concrete structures durability. In: International workshop on structural life management of underground structures. Daejon, South-Korea; 2011;51-6.

Wiktor V, Jonkers HM. The potential of bacteria-based repair system to increase the durability of repaired concrete structures. In: Guang Y, van Breugel K, Sun W, Miao C, editors. Microstructural-related durability of cementitious composites. Amsterdam: Rilem Publication S.A.R.L; 2012169169.

Wiktor V, Jonkers HM. Application of bacteria-based repair system to damaged concrete structures. In: 2nd international workshop on structural life management of underground structures. Daejon, South-Korea; 2012;31-4. 